\title{
FEDERAL CIVIL PROCEDURE: RESTRICTIVE INTERPRETATION OF SECTION I4O4(a) ADOPTED BY SUPREME COURT
}

$\mathrm{S}_{\text {ection }}$ 1404(a) of the Judicial Code provides that "for the convenience of the parties and witnesses, in the interest of justice, a district court may transfer any civil action to any other district or division where it might have been brought." In Hoffman v. Blaski, ${ }^{2}$ a patent infringement action, and in Sullivan v. Behimer, ${ }^{3}$ a stockholders' derivative suit, the respective defendants sought transfer to districts where the suits could not have been initiated because venue would have been improperly laid ${ }^{4}$ and service of process unavailable. ${ }^{5}$ In each case the Court of Appeals for the Seventh Circuit refused to permit transfer on the grounds that the words "where it might have been brought" limited transfer to districts where the suit could have been initiated without the defendants' consent. Specifically, the court held that the defendants could not secure transfer to the districts of their choice by waiving venue and process defects.

The Supreme Court affirmed this interpretation of the statute, three Justices dissenting. ${ }^{6}$ The opinion of the Court asserts that violence

\footnotetext{
${ }_{28}$ U.S.C. $\$ 1404$ (a) $\left(x_{95} 8\right)$.

${ }_{260}$ F.2d 317 (7th Cir. 1959). The action had been brought in the District
} Court for the Northern District of Texas, which granted the defendants' motion to transfer. The Court of Appeals for the Fifth Circuit refused to grant a writ of mandamus vacating the transfer order. Ex parte Blaski, 245 F.2d 737 (5th Cir.), cert. deried, 355 U.S. 872 (1957). In the receiving district, the District Court for the Northern District of Illinois, plaintiff moved to "remand" the action to the Northern District of Texas, and, on denial of the motion, petitioned the Court of Appeals for the Seventh Circuit for a writ of mandamus reversing the order.

${ }^{3}$ 26I F.2d 467 (7th Cir. 1958). The District Court for the Northern District of Illinois had granted the defendants' motion to transfer. The plaintiffs then petitioned for mandamus directing vacation of the transfer order.

'Venue in patent infringement litigation is provided for in 28 U.S.C. $\S 1400$ (b) (1958); venue provisions governing actions against corporations are found in 28 U.S.C. $\S$ I $391(c)(1958)$.

${ }^{5}$ FED. R. CIv. P. ${ }_{4}(f)$.

- Hoffman v. Blaski, 363 U.S. 335 (1960) (cases consolidated). The dissenters considered the cases separately. In Blaski they looked beyond the parties' stipulations and contended that considerations appurtenant to res judicata precluded the Seventh Circuit's re-examination of the Fifth Circuit's decision that transfer was proper. For discussion of the propriety of petitions for speciaI writs as a means of gaining appellate review 
would be done to an unequivocal statute if transfer to a district where the plaintiff did not originally "have a right" to bring suit were allowed.' Further, if transfer to any district were to follow upon defendants' waiver of venue and process objections, plaintiffs, having no comparable privilege, would be discriminated against. The basis of the decision, however, is the Court's analysis that transferor courts have no power to transfer unless the action "might have been brought" in the receiving district ${ }^{\$}$ and that a transferee district has no jurisdiction unless the action was validly transferred.

In a comprehensive dissent in the Sullivan case, Mr. Justice Frankfurter, argues that the statutory words are not unequivocal, citing the wide range of interpretation given them by lower courts. In his view, additionally, discrimination in any meaningful sense would not result from a liberal interpretation of the statute, since the interests of all parties are considered in determining whether the alternative forum will better serve convenience and justice; rather than discriminating against plaintiffs, a broad construction would merely temper their discriminatory choice-of-forum advantage. ${ }^{9}$ The dissent also points out that syllogistic analysis of the transferor court's power offers no help in determining where the action "might have been brought," for the determination is one of the locale where a lawsuit can conveniently be heard, not of the power of courts. Finally, because convenience itself is primarily at issue, the parties should be permitted to waive rules generally designed for their benefit when adherence to those rules proves inconvenient. 'In any event, a liberal interpretation of words that are concededly a

öf tränsfer orders, see In re Josephson, 218 F.2d 174 (1st Cir. 1954), and Magnetic Eng's \& Mfg. Co. v. Dings Mfg. Co., 178 F.2d 866 (2d Cir. 1950).

: 363 U.S. at 344 . The dissent criticizes this use of a verbal formula not found in" the "plain". words of the statute. Id. at 358 .

" " Accord, Fettig Canning Co. v. Steckler, 188 F.2d 715 (7th Cir.), cert. denied, 34I U.S. 951 (1951); Arvidson v. Reynolds Metals Co., 107 F. Supp. 51 (W.D. Wash. 1952); United States "v. I I Cases, etc., 94 F. Supp. 925 (D. Ore. 1950) (question 'considered to be onë of power).

The determination is clearly one of the power of the court in cases where jurisdiction "over the subject matter is involved. For example, in Lucas v. New York Cent. R.R., 88 F. Supp. 536 (S.D.N.Y. 1950), the motion to transfer was denied when diversity of citizenship would have been destroyed by the transfer; in Felchlin v. American Smelting \& Ref. Co., 136 F. Supp. 577 (S.D. Cal. 1955), the motion was denied where the plaintiff-administrator would have had no standing to sue in the 'receiving district.

$\because n$ Judge Holtżoff has also referred to this aspect of the statute with approval but, apparently; within the limitations prescribed by the instant decision. United States v. E.I. du' Poñt de Nemours \& Co.; 83 F. Supp. 233 (D.D.C. 1949). 
limitation on the operation of the statute does not deprive them of meaning, ${ }^{10}$ for defendants would nevertheless be-required to waive any objections to proceeding in the transferee district. ${ }^{11}$

Because the liberal interpretation of section $\mathrm{I}_{4} \mathrm{O}_{4}$ (a) advocated by the dissent would induce dilatory use of motions for transfer, ${ }^{12}$ an added burden would be imposed on district judges regardless of their ability to discern and summarily dispose of spurious motions. ${ }^{13}$ However, this burden would be mitigated in that liberal interpretation would tend to relieve congestion in the more "popular" districts. ${ }^{14}$

${ }^{10}$ See Paramount Pictures v. Rodney, 186 F.2d I11, I16 (3rd Cir. I950) (dissent), cert. denied, 340 U.S. 953 (195I); General Elec. Co. v. Central Transit Warehouse Co., 127 F. Supp. 8 I7 (W.D. Mo. 1955). See also 57 Mich. L. REv. 772 (I959).

${ }^{11}$ See Frechoux v. Lykes Bros. S.S. Co., I I 8 F. Supp. 234 (S.D.N.Y. 1953), and Greve v. Gibralter Enterprises, 85 F. Supp. 4 ro (D.N.M. 1949) (motion used to insure waiver of the defense of statute of limitations).

In Sheridan v. Pan American Ref. Corp., 123 F. Supp. 8 I (S.D.N.Y. 1954), and Curry v. States Marine Corp., 1 I 8 F. Supp. 234 (S.D.N.Y. 1954), the motions were denied when the defendants refused to waive the statute of limitations in the receiving districts.

12. The dissent contends that apprehension concerning the possibility of this burden vexing plaintiffs implies distrust of the competence of the district judges. ${ }_{36} 6_{3}$ U.S. at 368 .

Even, under the strict interpretation, a determination of whether service of process could have been had on a particular defendant at a particular time could lead to burdensome preliminary litigation.

... One district judge recognized the frequent use of the motion for transfer and its resultant work load. Kaufman, Observations on Transfer Under Section r4o4(a) of the Nequ Judicial Code, ro F.R.D. 595 (1951). However, he later concluded that the maximum convenience of the parties would be realized by allowing transfer to "the widest possible choice of forums." Kaufman, Further Observations on Transfers Under Section 1404 (a), 56 ColUM. L. REv. I, 18 (1956).

${ }^{13}$ To ensure that this preliminary maneuvering remains minimal, it seems desirable that the trial judge's discretion not be usurped by the appellate courts. See Chicago, R.I. \& P. R.R. v. Igoe, 220 F.2d 299, 305 (7th Cir. 1955) (dissent).

... In this opinion the Supreme Court-did not clarify the use of the special writs to effect what amounts to an appellate review of an interlocutory order. Compare Clayton v. Warlick, 232 F.2d 699 (4th Cir. 1956), and In re Josephson, 218 F.2d I74 (rst Cir. 1954), with Chicago, R.I. \& P., R.R. v. Igoe, supra.

14 Plaintiffs "frequently bring suit in districts noted for large jury verdicts." Such districts, usually serving large metropolitan areas, often have congested dockets, a condition which itself permits plaintiffs to coerce settlement from defendants apprehensive of long-pending litigation. Thus, a means should exist whereby these cases could be transferred to a more apporpriate forum, if one exists. The leading article on forum non conveniens suggested the use of that doctrine for this purpose. Blair, The Doctrine of Forum. Non Conveniens in Anglo-American Law, 29 CoLUM. L. REv. I (1929).

It seems apparent that the patent bar's recognition that certain districts are more 
Although some of the early interpretations of section $1404(a)$ are irreconcilable, ${ }^{15}$ a discernible pattern seems to have emerged. ${ }^{16}$ Plaintiffs have uniformly been denied transfer unless suit could properly have been initiated in the transferee district. ${ }^{17}$ Defendants, on the other hand, have been granted transfer to districts where they could have resisted suit, on the theory that a motion for transfer waives any objections the defendant may have had to the receiving district. ${ }^{18}$ Most of these decisions involved several defendants, at least one of whom was amenable to suit in the transferee district, ${ }^{10}$ but this factor was not always considered to be determinative. ${ }^{20}$ Prior to the Blaski decision in the Seventh Circuit, the trend apparently was toward a liberal interpre-

favorable to the holder of the patent in infringement actions was a major concern in the preliminary skirmishing displaying in the Blaski litigation. 57 Mich. L. REv. $77^{2}, 774$ n. 16 (1958). The problem of transferring patent litigation when the alternative districts display conflicting decisions was considered in Clayton v. Warlick, supra note 13.

${ }^{15}$ Compare Otto v. Hirl, 89 F. Supp. 72 (S.D. Iowa 1950) (plaintiff allowed transfer to district where defendant not amenable to process), with Barnhart v. John B. Rogers Prod. Co., 86 F. Supp. 595 (N.D. Ohio 1949) (statute held not applicable to plaintiffs). Compare Sheridan v. Pan American Ref. Corp., 123 F. Supp. 81 (S.D.N.Y. 1954) (defendant denied transfer to a district in which venue was improper), and Silbert v. Nu-Car Carriers, 11 I F. Supp. 357 (S.D.N.Y. 1953) (defendant denied transfer to district in which he was not amenable to process), with Hill v. Upper Mississippi Towing Corp., 141 F. Supp. 692 (D. Minn. 1956), and Welch v. Esso Shipping Co., 112 F. Supp. 61 I (S.D.N.Y. 1953) (defendants allowed transfer to districts in which they were not amenable to process and in which venue was improper).

${ }^{16}$ See Comment, Change of Venue in Federal Courts: Nequ Restrictions Upon Choice of Transferee Forum, 54 Nw. U.L. REv. 489 (1959), which also criticizes the decisions of the Court of Appeals for the Seventh Circuit in the instant cases.

${ }^{17}$ E.g., Foster-Milburn Co. v. Knight, 181 F.2d 949 (2d Cir. 1950). Contra, Troy v. Poorvu, 132 F. Supp. 864 (D. Mass. 1955), interpreting In re Josephson, 218 F.2d 174 (ist Cir. 1954). (1957).

${ }^{18}$ E.g., Ex parte Blaski, 245 F.2d 737 (5th Cir.), cert. denied, 355 U.S. 872

${ }^{10}$ Anthony v. Kaufman, 193 F.2d 85 (2d Cir. 1951), cert. denied, 342 U.S. 955 (1952); Paramount Pictures v. Rodney, 186 F.2d xx (3d Cir. 1950), cert. denied, 340 U.S. 953 ( 195 r).

In Continental Grain Co. v. Federal Barge Lines, Inc., 364 U.S. 19 (1960), 60 Colum. L. REv. 1035 ( 1960 ), an in rem action was held to be transferable because the owner of the res, also named as a defendant, was amenable to suit in the transferee district. Justices Frankfurter and Harlin concurred on the basis of their dissent in Blaski, and Justices Whittaker and Douglas dissented, contending the Blaski decision was controlling because the in rem action could have been brought only in that district in which the res was located.

${ }^{20}$ E.g., In re Josephson, 218 F.2d 174 (1st Cir. 1954). 
tation. ${ }^{21}$. Indeed, the Seventh Circuit's decision represents the first appellate court recognition of the restrictive interpretation finally adopted by the Supreme Court.

Forum non conveniens, the antecedent of section $1404(a)$, has been said to presuppose at least two forums in which the defendant is amenable to process. ${ }^{22}$ On this assumption it has been argued that transfer under section 1404 (a) is limited to districts where the defendant could originally have been sued. ${ }^{23}$ This argument is vulnerable in both premise and conclusion, for there are cases under the antecedent doctrine in which defendants procured dismissal by submitting to suit in forums where they were originally not subject to suit. ${ }^{24}$ Furthermore, since the statute is more than a mere codification of forum non conveniens, ${ }^{25}$ the common law requirement of two proper forums is irrelevant.

In support of the majority opinion, it is arguable that the Court's restriction on defendants' use of the statute is sound, considering the accepted limitations on plaintiffs' right of transfer. ${ }^{26}$ To allow defendants to transfer to any district, while restricting plaintiffs to those districts available under applicable venue and process requirements, could lead to forum shopping by defendants. ${ }^{27}$ It seems questionable

\footnotetext{
${ }^{22}$ General Cas. Co. v. Grubb, 253 F.2d 51 (7th Cir.), cert. denied, 357 U.S. 907 (1958); Ex parte Blaski, 245 F.2d 737 (5th Cir.), cert. denied, 355 U.S. 872 (1957). The dissent in Blaski v. Hoffman, 260 F.2d 317 (7th Cir. 1958), points out that a previous decision in that case, withdrawn on rehearing, had adopted the liberal view.

${ }^{22}$ Gulf Oil Corp. v. Gilbert, 330 U.S. 501 (1947).

${ }^{23}$ Chicago, R.I. \& P. R.R. v. Igoe, 212 F.2d 378 (7th Cir. 1954); Foster-Milburn Co. v. Knight, I 8 I F.zd 949 (2d Cir. 1950). But see In re Josephson, 2 I 8 F.2d I74, 185 (1st Cir. 1954), where this reasoning is termed a "gloss" on the statute.

${ }^{38}$ Canada Malting Co. v. Paterson S.S., Ltd., 285 U.S. 413 (1932), affirming 49 F.2d 802 (2d Cir. 1931); Vargas v. A. H. Bull S.S. Co., 44 N.J. Super. 536, 131 A.2d 39, aff'd per curiam, 25 N.J. 293, 135 A.2d 857 (1957), cert. denied, 355 U.S. $958(1958)$. "The Scottish Court will only treat itself as forum conveniens when the foreign trustees are either not liable or not willing to answer in the proper forum." Gibe, International. LAw of JuRisdiction 223 (1926). (Emphasis added.) Contra, Hill v. Upper Mississippi Towing Corp., 252 Minn. 165, 89 N.W.2d 654 (1958).

${ }^{25}$ Norwood v. Kirkpatrick, 349 U.S. 29 (1955). Compare United States v. National City Bus Lines, Inc., 337 U.S. 78 (1949), wit/ United States v. National City Bus Lines, Inc., 334 U.S. 573 (1948) (dismissal under forum non conveniens denied, but transfer under the statute allowed on same factual situation).

${ }^{20}$ The applicability of $\$ 1404$ (a) to plaintiffs is considered in Korbel, Plaintiff's Right to Change of Venue in Federal Courts, 38 U. DET. L.J. 137 (1960).

${ }^{27}$ I BarroN \& Hol.tzoff, Federal. Practice and Procedure $\$ 86.2$ (rev. ed. 1960). It has been pointed out, however, that this difficulty would be overcome
} 
whether the requirement that the transfer be for convenience and in the interest of justice would be sufficient restraint on this one-sided power of selection.

If each party to litigation is to be able to present his strongest case, the most convenient forum should be made available. Rules governing venue and service of process provide such a forum in a majority of cases. Inevitably, however, cases will arise in which a party can show that the specified district is inappropriate. Section I404(a), broadly interpreted, would have given federal district judges wide discretionary power to cope with such situations. Since the statute has not achieved that end, Congress should undertake its revision. ${ }^{28}$

if the statute were as completely applicable to plaintiffs as to defendants. Kaufiman, Further Observations on Transfers Under Section $1404(a), 56$ CoLUM. L. REV. 1,18 (1956). See also 60 YALE L.J. 183 (1951).

${ }_{38}$ The commentators have requested revision of the statute. Kaps, Venue Problems in" Bänkruptcy Proceedings, 14 RUTGERs L. REV. 749 (1960); Keefe, Venue and Reinoval Jokers in the New Federal Judicial Code, 38 VA. L. REV. 569 (1952); Korbel, supro note 26. 